\title{
Antimicrobial activity of Eucalyptus globulus oil, xylitol and papain: a pilot study
}

\author{
Atividade antimicrobiana do óleo de Eucalyptus globulus, xilitol e papaína: estudo piloto \\ Actividad antimicrobiana del aceite de Eucalyptus globulus, xilitol y papaína: estudio piloto
}

\author{
Valéria de Siqueira Mota ${ }^{1}$, Ruth Natalia Teresa Turrini², Vanessa de Brito Poveda ${ }^{3}$
}

\author{
${ }^{1}$ Nurse, Hospital Infection Control Committee, \\ Santa Casa de Misericórdia de Lorena, Lorena, \\ SP, Brazil. \\ ${ }^{2}$ Professor, School of Nursing, University of São \\ Paulo, São Paulo, SP, Brazil. \\ ${ }^{3}$ Professor, School of Nursing, University of São \\ Paulo, São Paulo, SP, Brazil.
}

\section{ABSTRACT}

Objective: To evaluate the in vitro antimicrobial activity of the Eucalyptus globulus essential oil, and of the xylitol and papain substances against the following microorganisms: Pseudomonas aeruginosa; Samonella sp.; Staphylococus aureus; Proteus vulgaris; Escherichia coli and Candida albicans. Method: The in vitro antimicrobial evaluation was used by means of the agar diffusion test and evaluation of the inhibition zone diameter of the tested substances. Chlorhexidine $0.5 \%$ was used as control. Results: The Eucalyptus globulus oil showed higher inhibition than chlorhexidine when applied to Staphylococcus aureus, and equal inhibition when applied to the following microorganisms: Escherichia coli, Proteus vulgaris and Candida albicans. Papain 10\% showed lower antimicrobial effect than chlorhexidine in relation to Candida albicans. Xylitol showed no inhibition of the tested microorganisms. Conclusion: The Eucalyptus globulus oil has antimicrobial activity against different microorganisms and appears to be a viable alternative as germicidal agent hence, further investigation is recommended.

\section{DESCRIPTORS}

Eucalyptus Globulus; Papain; Xylitol; Anti-Infective Agents; Infection Control; Nursing.

\section{Correspondence Addressed to:}

Vanessa de Brito Poveda

Escola de Enfermagem, Universidade de São Paulo

Av. Dr. Enéas de Carvalho Aguiar, 419 - Cerqueira César CEP 05403-000 - São Paulo, SP, Brazil

vbpoveda@usp.br 


\section{INTRODUCTION}

The germicidal adopted in healthcare settings, i.e., antiseptics or disinfectants are used indiscriminately, often at concentrations above the Minimum Inhibitory Concentration (MIC), which has boosted the emergence of microbial resistance to these agents too ${ }^{(1-2)}$.

The germicidal substances are used in various situations by acting at different sites of the microbial cell with bactericidal or bacteriostatic action, and important residual effect $^{(2)}$. Thus, antiseptic agents such as chlorhexidine are applied preferably for antisepsis of skin, mucosa and catheters, while disinfectants like hypochlorite may be used for cleaning counter tops and semi-critical or non-critical items ${ }^{(2-3)}$.

The indiscriminate use of germicidal impacts in the survival form of microorganisms, particularly bacteria, which have developed multiple mechanisms to overcome the available antimicrobial agents, from producing enzymes to inactivate drugs until genetic mutations and its transmission to new bacterial generations ${ }^{(4)}$.

The recognition of bacterial resistance problem brings the need to analyze the antimicrobial properties of new substances. Taking into account that Brazil is a country with rich flora diversity and capacity of developing agriculture, it is interesting and necessary to study plant-derived products as active principles of possible germicidal agents.

Xylitol stands out among these substances. It is a polyol composed of five carbon atoms obtained by the chemical industry from cane sugar. Xylitol has been used on a large scale by dental, food and medical and pharmaceutical industries. In addition, it has shown activity against biofilms in wounds $s^{(5)}$ and has been tested in animal models as a complementary measure in the treatment of osteomyelitis $^{(6)}$. Its activity against strains of Pseudomonas aeruginosa and Staphylococcus aureus ${ }^{(5)}$ is noteworthy.

Papain, another vegetable derived substance, is a proteolytic enzyme extracted from the fruits of papaya (Caricapapaya). It is known for its proteolytic and anti-inflammatory action and adopted as a topic debridement agent in skin wounds. The use of papain is indicated for clean and infected wounds at different phases of the healing process, and applied at different concentrations and/or presentations, according to the type of tissue in the wound bed. Bactericidal and bacteriostatic action is also attributed to papain, however, this evidence comes from studies of research designs, which are not capable of producing strong evidence ${ }^{(7)}$.

The extraction of plant-derived oils also stands out as a relatively cheap method and available worldwide, becoming an interesting alternative for the treatment of infections acquired in healthcare. The oil extracted from leaves of many Eucalyptus tree species is among the various types of oils studied. It belongs to the Myrtaceae family, native to Australia. This oil has been used especially to manufacture pharmaceutical inhalants, nasal discharge stimulants, oral care products, or even with the function of flavor and aroma to medicines. However, recent evidence points to possible effects associated with healing, anti-inflammatory and antimicrobial action ${ }^{(8)}$.
All aforementioned products are widely cultivated in Brazil and evaluating the potential of these substances can result in future investigations hypotheses. For example, the development of antiseptic or disinfectant products to address the emerging risk of reduction in sensitivity of the microorganisms to the germicidal agents available ${ }^{(9)}$. Another example is to stimulate discoveries related to the prevention and treatment of biofilms that slow or prevent the healing of wounds (especially in chronic wounds), generating high costs for treatment and associated morbidity and mortality ${ }^{(10)}$.

Therefore, the present study sought to evaluate the in vitro antimicrobial activity of the essential oil of Eucalyptus globulus, of xylitol and papain against the following microorganisms: Pseudomonas aureginosa; Samonella sp.; Staphylococus aureus; Proteus vulgaris; Escherichia coli and Candida albicans.

\section{METHOD}

This is a pilot study of qualitative laboratory type, developed in the Laboratory of Microbiology of a college located in the countryside of the state of São Paulo. Although the research project did not include humans in the analysis, it was approved by the Research Ethics Committee under number 107/2011.

\section{Procedure organization}

The microorganisms used in the study were selected for representing frequent agents in the occurrence of infections related to healthcare. Therefore, the following gramnegative bacteria were used: Pseudomonas aureginosa (BA 01 Nov./2012), Salmonella sp. (BA 02 Feb./2012), Proteus vulgaris (BA 03 Feb./2012) and Escherichia coli (BA 01 Aug./2011); and the gram-positive bacteria: Staphylococus aureus (BA 01 Feb./2012) and the fungus Candida albicans, acquired from the Control Lab company.

The products used in the tests were: $10 \%$ and $20 \% \mathrm{pa}^{-}$ pain; $10 \%$ and 20\% xylitol; and the essential oil of Eucalyptus globulus. The antiseptic used in health institutions, chlorhexidine $0.5 \%$, of the brand RIOHEX ${ }^{\circledR} 0.5 \%$ was considered as a reference for comparison.

The eucalyptus oil was extracted as follows: the plant was collected in a city in the Paraíba Valley region, state of São Paulo, in February 2012. The leaves were washed with clean water, exposed to dry air and subsequently placed in a Clevenger apparatus for obtaining oil by steam distillation technique, and the hydrodistillation method. The extracted Eucalyptus globulus essential oil remained in a labeled sterile bottle.

The papain powder was acquired in a compounding pharmacy and the xylitol powder was obtained from the laboratory of the Lorena Engineering School, University of São Paulo. Both products were diluted with sterile distilled water at $10 \%$ and $20 \%$, identified in sterile flasks with a final volume of 10 milliliters $(\mathrm{ml})$.

\section{LABORATORY PROCEDURES}

The antimicrobial in vitro evaluation by diffusion test in agar Brain Heart Infusion (BHI) was used because that 
is a qualitative test method suitable to study the sensitivity of rapid growth bacteria. The inhibition halo diameter expresses the agent diffusion, determining the antimicrobial power of the tested material ${ }^{(11)}$.

Microorganisms were plated by platinum loop into labeled vials containing five milliliters $(\mathrm{ml})$ of sterile nutrient broth and incubated at $36^{\circ} \mathrm{C}$ for 24 hours. After this period, each microorganism was seeded in two identified and sterile Petri dishes containing nutrient agar. The microorganisms were distributed with sterile swabs by the rolling technique in all the culture medium.

Sterile filter paper discs with one centimeter $(\mathrm{cm}) \mathrm{di}-$ ameter were soaked in the solutions with the aid of sterile forceps until complete absorption of the products used in the experiment and distributed in the culture media, properly identified and numbered.
All plates were placed in a bacteriological incubator at $36^{\circ} \mathrm{C}$ for $24 \mathrm{~h}$. After this time, the reading of the result was carried out with the naked eye and the inhibition zone was measured with a ruler ${ }^{(12)}$.

\section{RESULTS}

The inhibition halo caused by the products tested with the different microorganisms are shown in Table 1.

Chlorhexidine $0.5 \%$ was used as a reference (control) because this is a germicidal agent used in large scale in healthcare services.

Among the tested substances, only the eucalyptus oil showed inhibition superior to chlorhexidine in relation to the microorganism $S$. aureus, and equal inhibition in relation to the gram-negative microorganisms Escherichia coli, Candida albicans and Proteus vulgaris (Table 1).

Table 1 - Presentation of inhibition halo in centimeters $(\mathrm{cm})$, according to the product and microorganism tested - São Paulo, 2012.

\begin{tabular}{|c|c|c|c|c|c|c|c|}
\hline \multirow{3}{*}{ Classification } & \multirow{3}{*}{ Microorganisms } & \multicolumn{6}{|c|}{ INHIBITION ZONE (cm) } \\
\hline & & \multirow{2}{*}{$\begin{array}{c}\text { Control } \\
\text { Chlorhexidine } \\
0,5 \%\end{array}$} & \multicolumn{5}{|c|}{ Products tested } \\
\hline & & & $\begin{array}{l}\text { Eucalyptus } \\
\text { globulus (oil) }\end{array}$ & Papain $10 \%$ & $\begin{array}{l}\text { Papain } \\
\mathbf{2 0} \%\end{array}$ & $\begin{array}{c}\text { Xylitol } \\
10 \%\end{array}$ & $\begin{array}{c}\text { Xylitol } \\
\mathbf{2 0} \%\end{array}$ \\
\hline Gram + & Staphylococus aureus & 4 & 9 & 0 & 0 & 0 & 0 \\
\hline Gram - & Escherichia coli & 3 & 3 & 0 & 0 & 0 & 0 \\
\hline Gram - & Pseudomonas aeruginosa & 3 & 0 & 0 & 0 & 0 & 0 \\
\hline Gram - & Salmonella sp. & 4 & 0 & 0 & 0 & 0 & 0 \\
\hline Gram - & Proteus vulgaris & 5 & 5 & 0 & 0 & 0 & 0 \\
\hline Fungus & Candida albicans & 5 & 5 & 1,6 & 0 & 0 & 0 \\
\hline
\end{tabular}

Papain 10\% showed an inferior result compared to chlorhexidine, with inhibition of only $1.6 \mathrm{~cm}$ in relation to Candida albicans (Table 1).

Xylitol 10\%, xylitol 20\% and papain 20\% showed no inhibition in relation to the tested microorganisms (Table 1).

\section{DISCUSSION}

The discovery of new properties of previously known natural products and used for other purposes should be encouraged. Especially when we are faced with the emerging microbial resistance to the currently employed antimicrobial agents.

Among the substances tested in the present study, the Eucalyptus globulus essential oil stood out for its antimicrobial activity. In some tests with gram-negative microorganisms and fungi, its antimicrobial activity was similar to chlorhexidine, but it was higher than chlorhexidine in tests with gram-positive microorganisms traditionally associated with healthcare-related infections.

The result found is in agreement with the scientific literature recently produced, which tested the Eucalyptus globulus essential oil at different concentrations against strains of Escherichia coli and Staphylococcus aureus. The 100\% essential oil had the highest inhibition zone when compared to the other concentrations tested ${ }^{(11)}$. The action of the Eucalyptus globulus essential oil against strains of methicillin-resistant Sthaphylococcus aureus (MRSA) also stands out ${ }^{(13-14)}$.
However, the antimicrobial activity of Eucalyptus globulus oils seems to be lower in relation to some gram-negative bacteria such as Klebsiela, Pseudomonas and Acinectobacter ${ }^{(15)}$. The present study showed growth inhibition of the tested gram-negative microorganisms, i.e., the antimicrobial action of the Eucalyptus globulus oil was similar to chlorhexidine when applied to the Proteus and Escherichia coli bacteria, although it has not inhibited the growth of Pseudomonas e Salmonella.

In this study, it was also observed that although papain $10 \%$ was able to generate an inhibition zone of $1.6 \mathrm{~cm}$ in relation to the Candida albicans, this result was below the zone of inhibition of five centimeters achieved by chlorhexidine.

Similarly, another study tested different concentrations of papain gel formulation in relation to various microorganisms in vitro and the results showed bacterial inhibition only in relation to Staphylococcus aureus and Pseudomonas aeruginos a at a concentration of $10 \%{ }^{(16)}$.

The papain action as enzymatic debridement is remarkable, and in this sense, a study in mice with wounds intentionally contaminated with Escherichia coli found that papain outperformed the other tested products (collagenase and saline solution), allowing a rapid reduction in bacterial count, which contributed to the healing of injuries ${ }^{(17)}$.

However, the antimicrobial action of papain is little studied, and despite its embryonic phase, scientific evidences seem to demonstrate the potential action of this product 
against certain types of microorganisms ${ }^{(16-17)}$. Therefore, there is a need to test papain at other concentrations, checking its antimicrobial activity in vitro and in vivo particularly, since it is broadly used in the treatment of skin lesions and a reality in Brazilian health services.

Regarding xylitol, this product has been widely used by the food industry and studied by dentists in preventing plaque and tooth decay ${ }^{(18)}$. Nonetheless, in this study, there was no inhibition of microbial growth when using $10 \% \mathrm{xy}^{-}$ litol nor 20\% xylitol.

Xylitol has been indicated in the literature as an alternative for the prevention and treatment of oral and wound biofilm, and it has shown a moderate effect in inhibiting its growth ${ }^{(5)}$, which can be potentiated by combining xylitol with another substance called lactoferrin. Together, they would be able to destabilize the biofilm, with important effects on strains of Pseudomonas aeruginosa ${ }^{(19)}$.

Furthermore, in the presence of another carbon source, xylitol would be able to act on strains of Streptococcus pneumoniae originating from children with otitis media, interfering with the formation of biofilm ${ }^{(20)}$. This fact would be associated with the competence of xylitol to change the pneumococcal capsular structure ${ }^{(21)}$.

The biofilm is a persistent problem of difficult management, responsible for various medical problems, among which, the recurrence and poor healing of infected chronic wounds, loss of catheters and prostheses. Added to these aspects, there is also its progressive and rapid resistance to the antimicrobial agents currently used, such as chlorhexidine, showing a single therapy cannot be successful for its control, therefore, requiring a multifactorial approach ${ }^{(22-23)}$.

In light of this scientific evidence, it appears that although promising, xylitol must be combined with other substances to have its action enhanced and be an alternative for the prevention and treatment of biofilms. Thus, it is necessary to invest in research to find solutions to the problem of biofilm and fight it more efficiently.

\section{CONCLUSION}

It was found that Eucalyptus globulus essential oil has higher antimicrobial activity than chlorhexidine in relation to the Staphylococcus aureus gram-positive bacterium and the same antimicrobial activity for the following gram-negative bacteria: Escherichia coli and Proteus vulgaris, and the fungus Candida albicans.

Only papain $10 \%$ showed antimicrobial effect in relation to Candida albicans, and neither xylitol 10\%, nor xylitol 20\% showed antimicrobial effect.

Thus, the conclusion is that Eucalyptus globulus essential oil has antimicrobial activity against strains of different microorganisms and may be a viable alternative as germicidal agent. Further researches are recommended to expand the tests for other types of microorganisms, and also to explore its compatibility for use on human skin.

Given the observation of a discrete, but present antimicrobial action of papain, it is necessary to carry out other studies related to its antimicrobial action, especially in the treatment of chronic wounds, with designs to demonstrate ideal dosages or presentations of the substance in order to achieve better results.

Despite the promising effects of xylitol indicated in the literature, further research is recommended, particularly in combination with other substances.

In this sense, there are still many gaps to be filled in the scientific literature regarding the use of these substances and their possible pharmacological and germicidal properties.

\section{RESUMO}

Objetivo: Avaliar a atividade antimicrobiana in vitro do óleo essencial de Eucalyptus globulus e das substâncias xilitol e papaína, frente aos micro-organismos: Pseudomonas aeruginosa; Samonella sp.; Staphylococus aureus; Proteus vulgaris; Escherichia coli e Candida albicans. Método: Utilizou-se a avaliação antimicrobiana in vitro, por meio do teste da difusão em ágar e avaliação do diâmetro do halo de inibição das substâncias testadas. A clorexidina 0,5\% foi utilizada como controle. Resultados: Observou-se que o óleo de Eucalyptus globulus apresentou inibição superior à da clorexidina quando aplicado ao Staphylococus aureus, e inibição idêntica quando aplicado aos micro-organismos Escherichia coli, Proteus vulgaris e Candida albicans. A papaína 10\% apresentou efeito antimicrobiano inferior ao da clorexidina em relação à Candida albicans. $\mathrm{O}$ xilitol não apresentou inibição dos micro-organismos testados. Conclusão: $\mathrm{O}$ óleo de Eucalyptus globulus possui atividade antimicrobiana contra diferentes micro-organismos e parece ser uma alternativa viável como agente germicida, portanto, recomendam-se novas investigações.

\section{DESCRITORES}

Eucalyptus globulus; Papaína; Xilitol; Anti-Infecciosos; Controle de Infecções; Enfermagem.

\section{RESUMEN}

Objetivo: Evaluar la actividad antimicrobiana in vitro del aceite esencial de Eucalyptus globulus y las sustancias xilitol y papaína, ante los microorganismos: Pseudomonas aeruginosa; Samonella sp.; Staphylococus aureus; Proteus vulgaris; Escherichia coli y Candida albicans. Método: Se utilizó la evaluación antimicrobiana in vitro, por medio de la prueba de la difusión en agar y evaluación del diámetro del halo de inhibición de las sustancias probadas. La clorhexidina al 0,5\% fue utilizada como control. Resultados: Se advirtió que el aceite de Eucalyptus globulus presentó inhibición superior a la de la clorhexidina cuando aplicado al Staphylococus aureus, e inhibición idéntica cuando aplicado a los microorganismos Escherichia coli, Proteus vulgaris y Candida albicans. La papaína al $10 \%$ presentó efecto antimicrobiano inferior al de la clorhexidina con relación a la Candida albicans. El xilitol no presentó inhibición de los microorganismos probados. Conclusión: El aceite de Eucalyptus globulus tiene actividad antimicrobiana contra diferentes microorganismos y parece ser una alternativa viable como agente germicida, por lo que se recomiendan nuevas investigaciones

\section{DESCRIPTORES}

Eucalyptus globulus; Papaína; Xilitol; Antiinfecciosos; Control de Infecciones; Enfermería. 


\section{REFERENCES}

1. Padovani CM, Graziano KU, Goveia VR. Microbiological evaluation of different antiseptic povidone-iodine and chlorhexidine formulations after intentional contamination of containers. Rev Latino Am Enfermagem. 2008;16(6):1038-41.

2. Reis LM, Rabello BR, Ross C, Santos LMR. Avaliação da atividade antimicrobiana de antissépticos e desinfetantes utilizados em um serviço público de saúde. Rev Bras Enferm. 2011;64(5):870-5.

3. Ferreira MVF, Andrade D, Ferreira AM. Infection control related to central venous catheter impregnated with antiseptics: an integrative review. Rev Esc Enferm USP [Internet]. 2011 [cited 2014 Sep 11];45(4):1002-6. Available from: http://www.scielo.br/pdf/reeusp/v45n4/ en_v45n4a30.pdf

4. Nikaido H. Multidrug resistance in bacteria. Annu Rev Biochem. 2009;78:119-46.

5. Ammons MC, Ward LS, James GA. Anti-biofilm efficacy of a lactoferrin/xylitol wound hydrogel used in combination with silver wound dressings. Int Wound J. 2011;8(3):268-73.

6. Beenken KE, Bradney L, Bellamy W, Skinner RA, McLaren SG, Gruenwald MJ, et al. Use of xylitol to enhance the therapeutic efficacy of polymethylmethacrylate-based antibiotic therapy in treatment of chronic osteomyelitis. Antimicrob Agents Chemother. 2012;56(11):583944.

7. Leite AP, Oliveira BGRB, Soares MF, Barrocas DLR. Uso e efetividade da papaína no processo de cicatrização de feridas: uma revisão sistemática. Rev Gaúcha Enferm. 2012;33(3):198-207.

8. Warnke PH, Becker ST, Podschun R, Sivananthan S, Springer IN, Russo PA, et al. The battle against multi-resistant strains: renaissance of antimicrobial essential oils as a promising force to fight hospital-acquired infections. J Craniomaxillofac Surg. 2009;37(7):392-7.

9. Harbarth S, Tuan SS, Horner C, Wilcox MH. Is reduced susceptibility to disinfectants and antiseptics a risk in healthcare settings? A point/ counterpoint review. J Hosp Infect. 2014;87(4):194-202.

10. Zhao G, Usui ML, Lippman SI, James GA, Stewart PS, Fleckman P, et al. Biofilms and inflammation in chronic wounds. Adv Wound Care (New Rochelle). 2013;2(7):389-99.

11. Brasil. Ministério da Saúde; Agência Nacional de Vigilância Sanitária. Detecção e identificação de bactérias de importância médica: módulo V. Brasília: ANVISA; 2004.

12. Clinical and Laboratory Standards Institute. Performance standards for antimicrobial disk susceptibility tests; informational supplement seventeenth edition. Document M100-S17. NCCLS. 2007;27(1):1-173.

13. Bachir Raho G, Benali M. Antibacterial activity of the essential oils from the leaves of Eucalyptus globulus against Escherichia coli and Staphylococcus aureus. Asian Pac J Trop Biomed. 2012;2(9):739-42.

14. Tohidpour A, Sattari M, Omidbaigi R, Yadegar A, Nazemi J. Antibacterial effect of essential oils from two medicinal plants against Methicillin-resistant Staphylococcus aureus (MRSA). Phytomedicine. 2010;17(2):142-5.

15. Mulyaningsih S, Sporer F, Reichling J, Wink M. Antibacterial activity of essential oils from Eucalyptus and of selected components against multidrug-resistant bacterial pathogens. Pharm Biol. 2011;49(9):893-9.

16. Ferreira AM, Watanabe E, Nascimento AP, Andrade D, Ito IY. Atividade antibacteriana in vitro de géis com diferentes concentrações de papaína. Rev Eletr Enferm [Internet]. 2008 [citado 2014 jul. 19];10(4):1035-40. Disponível em: http://www.fen.ufg.br/fen_revista/v10/n4/ pdf/v10n4a15.pdf

17. Payne WG, Salas RE, Ko F, Naidu DK, Donate G, Wright TE, et al. Enzymatic debriding agents are safe in wounds with high bacterial bioburdens and stimulate healing. Eplasty. 2008;8:e17.

18. Zhan L, Featherstone JD, Lo J, Krupansky C, Hoang N, DenBesten P, et al. Clinical efficacy and effects of xylitol wipes on bacterial virulence. Adv Dent Res. 2012;24(2):117-22.

19. Ammons MC, Ward LS, Dowd S, James GA. Combined treatment of Pseudomonas aeruginosa biofilm with lactoferrin and xylitol inhibits the ability of bacteria to respond to damage resulting from lactoferrin iron chelation. Int J Antimicrob Agents. 2011;37(4):316-23.

20. Kurola P, Tapiainen T, Sevander J, Kaijalainen T, Leinonen M, Uhari M, et al. Effect of xylitol and other carbon sources on Streptococcus pneumoniae biofilm formation and gene expression in vitro. APMIS. 2011;119(2):135-42.

21. Kurola P, Tapiainen T, Kaijalainen T, Uhari M, Saukkoriipi A. Xylitol and capsular gene expression in Streptococcus pneumoniae. J Med Microbiol. 2009;58(Pt11):1470-3.

22. Percival SL, Finnegan S, Donelli G, Vuotto C, Rimmer S, Lipsky BA. Antiseptics for treating infected wounds: efficacy on biofilms and effect of pH. Crit Rev Microbiol. 2014 Aug 27:1-17. [Epub ahead of print].

23. Stojicik S, Shen Y, Haapasalo M. Effect of the source of biofilm bacteria, level of biofilm maturation, and type of disinfecting agent on the susceptibility of biofilm bacteria to antibacterial agents. J Endod. 2013;39(4):473-7. 